\title{
Abbreviations of key archives, documents, names
}

\author{
Akademie \\ Zuid-Afrikaanse Akademie voor Taal, Letteren en Kunst (South African Academy for \\ Language, Literature and Art) \\ ANC \\ ARCA \\ African National Congress \\ ATKV \\ Archive for Contemporary Affairs, University of the Free State, Bloemfontein \\ AWB \\ Afrikaanse Taal en Kultuurvereniging (Afrikaans Language and Culture Association) \\ Broederbond \\ Afrikaner Weerstandsbeweging (Afrikaner resistance movement) \\ Dagbestuur \\ Afrikaner Broederbond (Afrikaner Brotherhood) \\ Dagbestuurkomitee (Executive or Management Committee), SVK. Minutes and documents \\ cited are from NARSSA, A141 vols 1-2, unless otherwise referenced \\ DNMCH \\ FAK \\ Foldout \\ Ditsong National Museum of Cultural History, Pretoria \\ Federasie van Afrikaanse Kultuurverenigings (Federation of Afrikaner Cultural Organisations) \\ HF Archives ATP \\ HF Archives $F$ \\ HF Archives HF \\ HF Archives VTM \\ Foldout at the end of the book showing the entire frieze as installed in the Hall of Heroes \\ Heritage Foundation Archives at VTM, Pretoria: Plans and Drawings Collection \\ Heritage Foundation Archives at VTM, Pretoria: Photographic Collection \\ Heritage Foundation Archives at VTM, Pretoria: Heritage Foundation Collection \\ Heritage Foundation Archives at VTM, Pretoria: Voortrekker Monument Collection \\ (subsections include SVK for Sentrale Volksmonumente Komitee papers; BHR for \\ Beheerraad, Board of Control) \\ Jansen Memorandum Memorandum from SVK chair Jansen to Minister of Interior about the site and the design of \\ the Voortrekker Monument, including a list of twenty-four scenes for the frieze. NARSSA, \\ BNS 146/73/2, 19.1.1937 \\ Kirchhoff files \\ Kirchhoff family files, Johannesburg \\ Moerdyk Layout \\ Gerard Moerdyk's first layout of the frieze with thirty-one panels. ARCA PV94 1/75/1/8 \\ (Jansen). Undated, but datable between SVK 5.10.1936 and SVK 15.1.1937 \\ uMsunduzi Museum \\ uMsunduzi Museum Collection (incorporating the Voortrekker Complex), Pietermaritzburg \\ Collection \\ Museum Africa \\ Museum Africa (1933-94 'Africana Museum'), Johannesburg \\ NA Den Haag \\ Nationaal Archief, The Hague \\ NA Kew \\ NARSSA \\ The National Archives of the United Kingdom, Kew \\ NARSSA Cape Town \\ NHKA \\ National Archives and Records Service of South Africa, Pretoria \\ National Archives and Records Service of South Africa, Cape Town \\ Nederduitsch Hervormde Kerk in Afrika Argief (Dutch Reformed Church in Africa Archive), \\ Pretoria \\ Official Guide \\ OVS/OFS \\ The Voortrekker Monument, Official Guide, 1955-76 (see Bibliography) \\ Panele \\ Oranje-Vrijstaat (Orange Free State) \\ Panels. ARCA PV94 1/75/1/9 (Jansen). Undated proposal of fourteen themes for historical \\ reliefs, c. 1934-36 \\ Romanelli files Romanelli family files, Florence (Italy) \\ SUN Africana \\ Stellenbosch University, Special Collections, Africana \\ SVK \\ Sentrale Volksmonumentekomitee (Central People's Monuments Committee). Minutes and \\ documents cited for the SVK and its subcommittees (listed below) are from NARSSA, A141, \\ vols 1-2, unless otherwise referenced \\ Boukomittee Building Committee, SVK \\ Dagbestuur Dagbestuurkomitee (Executive/Management Committee), SVK \\ Historiese Komitee Historical Committee, SVK \\ Paneelkomitee Panel Committee, SVK \\ Vormkomitee Form Committee, SVK
}


UCT

UCT Thompson

Unisa Archives

UP Archives

Van Schaik album

Voorstelle

VTM

VTM Museum

Wenke
University of Cape Town

UCT Libraries, Special Collections, BC 643 Joyce Newton Thompson Collection (http://atom.lib.uct.ac.za/index.php/joyce-newton-thompson-collection)

University of South Africa, Department of Library Services, Pretoria

University of Pretoria Archives, Art Archives and Gerard Moerdyk Collection

Unisa Archives, J.L. van Schaik Publishers, Photographic album 1949, Voortrekker Monument inauguration

Voorstelle van tonele uit die tyd van die Voortrek wat geskik geag word vir half- en hoogverhewe beeldwerk op the Voortrekkermonument (Suggestions of scenes from the time of the Trek considered appropriate for bas and high relief work on the Voortrekker Monument). NARSSA, 140/3/14 (Engelenburg), pp.112-113; ARCA PV94 1/75/1/9 (Jansen). Undated, probably attachment of SVK 5.12.1934

Voortrekker Monument Heritage Site, Pretoria

Voortrekker Monument Heritage Site, Pretoria: Voortrekker Monument Museum collection Wenke i.v.m. historiewe [sic] tonele vir die Voortrekkermonument (Suggestions in relation to historical scenes for the Voortrekker Monument). ARCA PV94 1/75/1/9 (Jansen). Undated list of suggestions from individuals for historical reliefs, c. 1934-36

Zuid-Afrikaansche Republiek (South African Republic; nineteenth century) 
